\title{
CHAPTER 13 \\ Health Climate Justice and Deforestation in the Amazon
}

\author{
Virgilio Viana
}

Summary Health is a dimension of tropical deforestation that deserves greater attention in light of the current trends in climate change, environmental degradation and national and subnational development policies. Forest fires are becoming more frequent and larger in scale globally (Baccini et al., 2017). Deforestation fuels global warming, and reducing forest fires is essential to meet the Paris Agreement targets (UNEP, 2018).

Climate change is affecting rainfall regimes, including the length of dry seasons, which fuels forest fires and thus creates a feedback loop mechanism. Increased fire frequency results in air pollution, which is associated with a number of health problems. Ambient air pollution accounts for an estimated 4.2 million deaths per year due to stroke, heart disease, lung cancer, and chronic respiratory diseases. Around $91 \%$ of the world's population lives in places where air quality levels exceed World Health Organization (WHO) limits (WHO, 2019).

The Amazon is home to 34 million people who are exposed to air pollution associated with forest fires. This includes more than 380 indigenous groups of peoples who suffer from one of the greatest climate injustices: despite having had a very low carbon footprint, they are facing the consequences of climate change, including health problems associated with air pollution from forest fires. Reducing deforestation and forest fires is relevant both for local populations and for mitigating global climate change.

This chapter analyzes the linkages between health, air pollution and forest fires in the Amazon. The goal is to highlight the importance of having an understanding of the complexity of these linkages to encourage further research and policy approaches.

\footnotetext{
V. Viana $(\square)$

Sustainable Amazon Foundation (FAS), Cambridge, MA, USA

e-mail: virgilio.viana@fas-amazonas.org
} 


\section{Deforestation and Fires in the Amazon}

The Amazon is the largest tropical rainforest in the world, covering 6.7 million hectares, spreading across eight countries and one province: Brazil (64.3\%), Peru (10\%), Bolivia (6.2\%), Colombia (6.2\%), Venezuela (5.8\%), Guyana (2.8), Suriname (2.1\%), Ecuador (1.5\%), and French Guiana (1.1\%) (RAISG, 2015). While Brazil has $71.5 \%$ of the Amazon Basin, it has only $64.3 \%$ of the Amazon Biome. The Amazon Basin represents $66 \%$ of the Brazilian territory, while the Amazon Biome represents $58.8 \%$ of the country area. By contrast, Suriname and French Guiana have practically no area in the Amazon Basin, while having $100 \%$ of their territory in the Amazon Biome (Table 13.1). The Amazon is extremely diverse in both biophysical and human dimensions. Therefore, this heterogeneity and complexity has to be considered and generalizations for the region should be taken with caution. This chapter focuses on Brazil, but most of the data and conclusions are also relevant to other Amazonian countries.

The Amazon plays a vital role for the earth's climate as a mega-provider of ecosystem services, including storage of live carbon (176.297 million tons/25\% of global storage) (FAO, 2011), conservation of biodiversity (over 10\% of total species) and a water pump to the atmosphere (over 20 billion tons of water every day) (Nobre, 2014). The Amazon generates approximately half of its own rainfall by recycling moisture five to six times as air masses move from the Atlantic across the basin to the west (Salati et al., 1979).

Deforestation continues at an alarming rate: $7.900 \mathrm{~km}^{2}$ in 2018 in Brazil alone, an increase of $13.7 \%$ from 2017 (INPE, 2019). Forest fires have increased similarly. The Amazon has warmed, reaching $0.6-0.7{ }^{\circ} \mathrm{C}$ over the last 40 years, with 2016 as the warmest year since at least $1950\left(0.9{ }^{\circ} \mathrm{C}+0.3{ }^{\circ} \mathrm{C}\right)$. The dry-season length increased and more climate extremes affect the region with impacts on carbon sequestration and storage, river streamflow, and biodiversity, even in the large forested areas designated to conservation and protection (Marengo et al., 2018).

Recent studies have demonstrated that interactions between deforestation, fire, and severe drought potentially lead to losses of carbon storage and changes in regional precipitation patterns and river discharge (Davidson et al., 2012). A study in the state of Rondonia, Brazil-a region that has been continuously deforested since the 1970s - indicates that in areas highly deforested, the beginning of the rainy season has significantly shifted to, on average, 11 days (and up to 18 days) later in the year over the last three decades. However, in areas that have not been heavily deforested, that did not happen. Delayed onset of rains may be a result of land use change, and this signal may strengthen in future (Butt et al., 2011).

Amazon forest's susceptibility to fires during extreme events is not only driven by climate, but also the previous disturbance history, and modulated by forest structure. Heavily degraded forests with low canopy cover and biomass suffer water stress and increased flammability earlier in the drought period than old-growth forests (Longo et al., 2018). 
Table 13.1 Land and environmental profile of Amazon countries

\begin{tabular}{|c|c|c|c|c|c|c|}
\hline Country & $\begin{array}{l}\text { Total area } \\
\text { (million } \\
\mathrm{km}^{2} \text { ) }\end{array}$ & $\begin{array}{l}\% \text { of total } \\
\text { Amazon basin } \\
\text { found in each } \\
\text { country }\end{array}$ & $\begin{array}{l}\% \text { of } \\
\text { Amazon } \\
\text { basin for } \\
\text { each country }\end{array}$ & $\begin{array}{l}\% \text { of total } \\
\text { Amazon } \\
\text { biome found } \\
\text { in each } \\
\text { country }\end{array}$ & $\begin{array}{l}\% \text { of } \\
\text { Amazon } \\
\text { biome for } \\
\text { each country }\end{array}$ & $\begin{array}{l}\% \\
\text { forest } \\
\text { loss }\end{array}$ \\
\hline Brasil & $8,516,000$ & 71.5 & 66 & 64.3 & 58.8 & 17.6 \\
\hline Bolivia & $1,099,000$ & 9.2 & 66 & 6.1 & 43.2 & 7.3 \\
\hline Colombia & $1,142,000$ & 4.4 & 30 & 6.2 & 42.3 & 9.9 \\
\hline Equador & 283,560 & 1.8 & 51 & 1.5 & 41.1 & 10.7 \\
\hline Guyana & 214,970 & 0.1 & 5 & 2.8 & 100 & 2.5 \\
\hline French Guiana & 83,534 & 0 & 0 & 1.1 & 100 & 2.8 \\
\hline Peru & $1,285,000$ & 12.3 & 75 & 10.1 & 60.9 & 9.1 \\
\hline Suriname & 163,821 & 0 & 0 & 2.1 & 100 & 4.2 \\
\hline Venezuela & 916,445 & 0.7 & 6 & 5.8 & 49.5 & 3.3 \\
\hline Total & $13,704,330$ & 100 & & 100 & & 6.2 \\
\hline
\end{tabular}

Source: SDSN-Amazonia at https://www.sdsn-amazonia.org/pt-plataforma

\section{Amazon Tipping Point}

A suite of general circulation model projections generally agrees, showing robust cross-model drying in the Amazon and other regions (Cook et al., 2014). This can generate feedback loops given the fact that the Amazon generates approximately half of its own rainfall by recycling moisture five to six times as air masses move from the Atlantic across the basin to the west (Salati et al., 1979).

Negative synergies between deforestation, climate change, and widespread use of fire indicate a tipping point for the Amazon system to flip to non-forest ecosystems in eastern, southern, and central Amazonia at 20-25\% deforestation (Lovejoy $\&$ Nobre, 2018). However, with the combined stress of rising temperature, deforestation, and increased forest fires, the tipping point may be reached significantly earlier. To date, almost $18 \%$ of the Amazonian basin has been deforested (Gaffney et al., 2018). While there is scientific uncertainty about the tipping point (Fig. 13.1), the precautionary principle recommends setting a goal for zero net deforestation no later than 2025-preferably earlier.

There are already signs of a transition to a disturbance-dominated regime in the Amazon, driven by interactions between deforestation, fire, and drought, potentially leading to losses of carbon storage and changes in regional precipitation patterns and river discharge (Davidson et al., 2012).

The Amazon biodiversity is highly vulnerable to climate change. The Amazon contains one of Earth's richest assortments of biodiversity with recent compilations indicating at least 40,000 plant species, 427 mammals, 1294 birds, 378 reptiles, 427 amphibians, 3000 fishes, and likely over a million insect species (Case, 2006). Even a $2{ }^{\circ} \mathrm{C}$ rise would make the new average temperature hotter than previous extremes, and would threaten more than one-third of species in all groups in the absence of 


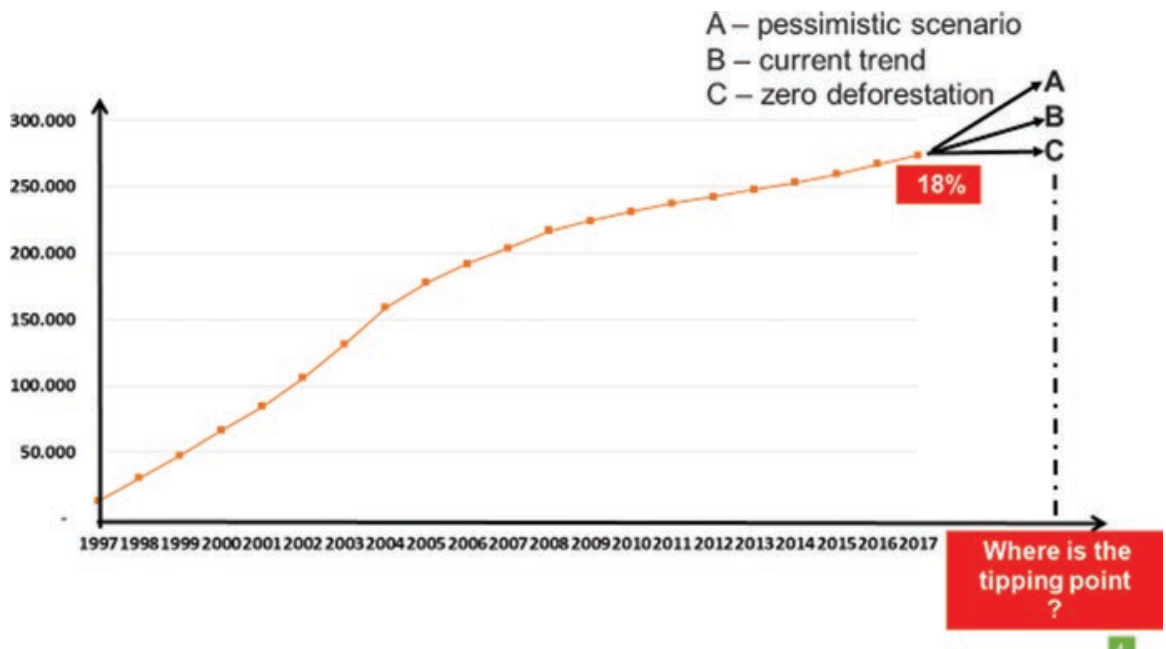

Fig. 13.1 Cumulative deforestation in the Brazilian Amazon $\left(\mathrm{km}^{2}\right)$. Based on official deforestation data (http://www.inpe.br)

dispersal. A business-as-usual scenario would see this figure increase to around two-thirds (WWF, 2018).

\section{Forest Fires and Health}

Forest fires increase air pollution, and this results in health problems. Evidence on the nexus between forest fires, air pollution and health is not new. Human health impacts of forest fires include biophysical effects, psychosocial impacts, occupational exposure issues among fire crew members, and visibility impairment (Fowler, 2003). A recent literature review of public health issues caused by forest fires between 1990 and 2018 presented evidence on mortality, respiratory and cardiovascular morbidity as well as other possible impacts on human health (CancedoGonzález \& Viqueira, 2018).

A study of 13.5 years of data including 48 days affected by wildfire smoke in Sydney, Australia, demonstrated a significant increase in mortality associated with smoke-affected days (Johnston et al., 2011). An earlier study of mortality in Sydney, using 8 years of data, found an increase in mortality associated with wildfire-related PM10 (Morgan et al., 2010). An analysis of forest fires that blanketed the Indonesian islands of Kalimantan and Sumatra in late 1997 found that individuals who were exposed to haze experienced greater increases in difficulty with activities of daily living and that haze had a negative impact on respiratory and general health (Frankenberg et al., 2005). A meta-analysis of data from 2003 to 2010 in 10 cities in southern Europe found increases in cardiovascular mortality associated with 
PM10 that were stronger on smoke-affected days than on non-affected days (Faustini et al., 2015).

Large-scale intentional forest fires in Indonesia cause haze in neighboring countries. The causal impact of these fires on Singaporean health outcomes had estimated partial health and avoidance costs of US\$184 million from September 2012 to August 2017 (Sankaran \& Sheldon, 2018). A study on prenatal exposure to the 1997 Indonesian forest fires based on child nutritional outcomes found that mean exposure to air pollution during the prenatal stage was associated with a 0.5 standard deviation decrease in height-for-age $z$ score at age 17. Because adult height is associated with income, this implies a loss of $4 \%$ of average monthly wages for approximately one million Indonesian workers born during this period (Tan-Soo \& Pattanayak, 2019).

An analysis of hospitalizations due to respiratory diseases in people over 60 years of age who were residents of Cuiabá in the Brazilian Amazon during 2012 found significant correlations between exposure to these contaminants and hospitalizations. There was a hospitalization risk increase of $31.8 \%$, with an increase of $3.5 \mu \mathrm{g} / \mathrm{m}^{3}$ of PM2.5 concentrations and an increase of 188 in the total number of hospitalizations (Machin et al., 2019).

The spatial variability of aerosols over Amazon Basin shows that large areas of three to five million $\mathrm{km}^{2}$ are affected by high aerosol concentrations. The concentration of trace gases and aerosols from forest fires in the dry season increase by factor of 2-8 in large areas (Artaxo et al., 2006).

A $10 \mu \mathrm{g} / \mathrm{m}^{3}$ increase in the level of exposure to particulate matter in the Amazon was associated with increases of $2.9 \%$ and $2.6 \%$ in outpatient consultations due to respiratory diseases in children on the sixth and seventh days following exposure, respectively. Levels of particulate matter from biomass burning in the Amazon were associated with adverse effects on the respiratory health of children (Carmo et al., 2010). A cross-sectional analysis of cardiovascular mortality among people over 65 years in the Brazilian Amazon, where the predominant source of air pollution is from wildfires, found a significant association between the percentage of hours of PM2.5 over $25 \mu \mathrm{g} / \mathrm{m}^{3}$ and cardiovascular mortality (Nunes et al., 2013).

\section{Implications for Public Policies and Research}

Considering the fact that there is clear evidence that forest fires are directly correlated to health problems, and that climate change is likely to increase the magnitude of this problem, there is urgency for action.

Deforestation is a result of a complex sum of factors, which vary both in space and time. Therefore, it is necessary to take into account this complexity to understand the dynamics of deforestation. Drivers of deforestation can be grouped into (1) economic factors (market structure, conditions and access to credit, incentives, prize of commodities, international demand, etc.), (2) governance factors (budget and structure of environmental institutions, efficiency of command and 
control instruments, management efficacy of protected areas and indigenous lands); (3) political factors (power of the lobby of the agricultural sector; changes in legislation at the federal, state and municipal levels), (4) infrastructure development (road construction, hydroelectric dams, etc.) and development of extractive industries (mining, oil, and gas), and (5) structural factors (population growth and migration, poverty and inequality, etc.). Reducing deforestation and forests fires, therefore, is no simple task (Viana, 2017).

A roadmap for action should include a mix of policy instruments to: (1) strengthen governance in the frontier, (2) increase funding mechanisms for sustainable development in the Amazon, (3) change the paradigm of financing for infrastructure, (4) reduce corruption and increase transparency, (5) improve corporate behavior, (6) strengthen civil society organizations, (7) education and communication, (8) ecosystem services and poverty, (9) promote community-based sustainable development pathways, especially in protected areas and indigenous lands, and (10) build political support (Viana, 2017).

Environmental policies have had a setback in recent elections in Brazil, both at the national and subnational levels. There is a general perception that environmental policies are slowing economic growth and thus need to be weakened (Viana, 2019).

The connection between deforestation, forest fires and health can be an important tool to change environmental policies in the Amazon. Health relates directly to the interests of all citizens and their family members. High air pollution is seen and easily understood by the general public. Health problems are publicized in the media, and this creates an opportunity to drive policy change.

Institutions engaged in the design and implementation of environmental public policies should give greater emphasis to the health dimension of deforestation. The same applies to those engaged in public health public policies: they should emphasize the forest fire-health nexus. There is a need for a massive communication strategy to create greater public awareness and thus influence policy-making on the forest fire-health nexus.

There are some questions that require attention in the design and implementation of sound public policies: How can we communicate effectively and promote dialogue on public policies associated with the forest fires, air pollution, and health? How can we disseminate research results on the nexus between forest fires, air pollution, and health?

Although the body of evidence is quite sufficient for practical action, there are several research questions that deserve further work: How can we address the ethical components of climate injustice towards indigenous peoples and isolated communities and their linkages to health and forest fires? How can we improve public health systems to deliver health care to problems associated with air pollution in the Amazon, especially for indigenous peoples and isolated communities? How can we improve the understanding of the consequences of air pollution to public health in the Amazon? What are the scenarios for forest fires, air pollution, and health in their short term and long term in light of climate change? 


\section{Conclusions and Call to Action}

Public policies in the Amazon aimed at reducing deforestation and forest fires are traditionally driven by an environmental rationale, without appropriate consideration to the human health dimension. Public health policies do not give due consideration to air pollution derived from forest fires. Climate policies do not give the necessary attention to forest fires. This needs to change if the Amazon is to succeed in meeting the Sustainable Development Goals by 2030.

A better understanding of the nexus between forest fires and health can change societal perceptions and become drivers of necessary change in public policies. This is key to strengthen policies aimed at reducing forest fires in the Amazon.

There is a need for urgent action to avoid the tipping point of the Amazon forest, which would have profound consequences for Brazil, South America, and the planet. The following actions are recommended:

1. Policy dialogue, design, and implementation of cross-sectoral policies aiming at zero deforestation in all nine Amazon countries by 2025. The process should be informed by science and supported by massive communication about the health-deforestation nexus, in all Amazon regions. Other regions of South America should be informed about the importance of the Amazon to maintain rainfall regimes. Zero net deforestation policies should include reforestation, such as agroforestry systems to boost resilience and compensate for residual deforestation. Research on the efficacy and efficiency of different policy instruments should be supported.

2. New financial mechanisms to support implementation of zero net deforestation policies. These mechanisms should include a carbon tax and payments for ecosystem services to compensate Amazon populations, especially indigenous peoples, for the benefits (carbon, biodiversity, water, others) provided by their forests. Research on the importance and value of the Amazon for rainfall regimes and climate stability in the region and globally should be supported.

3. Health policies to improve care for air pollution-related diseases. These policies should have a special focus on indigenous peoples, who suffer from one of the world's greatest climate injustices, because they have not been part of the problem of greenhouse gas emissions. Research on the health impacts and appropriate care for deforestation-borne air pollution should be supported.

4. Develop new partnerships engaging the business and civil society organizations in the design and implementation of practical solutions for sustainable development of the Amazon. These solutions should support national and subnational governments to increase efficiency, efficacy and transparency. These partnerships should be broad, including local, national and global actors. The Amazon is too big to fail. 


\section{References}

Artaxo, P., Oliveira, P. H., Lara, L. L., Pauliquevis, T. M., Rizzo, L. V., Pires Junior, C., et al. (2006). Efeitos climáticos de partículas de aerossóis biogênicos e emitidos em queimadas na Amazônia. Revista Brasileira de Meteorologia, 21, 168-122. Retrieved from http://sigma. cptec.inpe.br/aerossois/documentos/LBA040-2006_PArtaxo.pdf

Baccini, A., Walker, W., Carvalho, L., Farina, M., Sulla-Menashe, D., \& Houghton, R. A. (2017). Tropical forests are a net carbon source based on aboveground measurements of gain and loss. Science, 358, 230-223. Retrieved from http://science.sciencemag.org/content/358/6360/230

Butt, N., de Oliveira, P. F., \& Costa, M. H. (2011). Evidence that deforestation affects the onset of the rainy season in Rondonia, Brazil. Journal of Geophysical Research, 116, D11120. Retrieved from https://agupubs.onlinelibrary.wiley.com/doi/epdf/10.1029/2010JD015174

Cancedo-González, \& Viqueira. (2018). Forest fires and public health. Anales de la Real Academia Nacional de Farmacia, 84, 289-300. Retrieved from https://www.analesranf.com/index.php/ aranf/article/download/1902/1888

Carmo, C. N., Hacon, S., Longo, K. M., Freitas, S., Ignotti, E., Leon, A. P., et al. (2010). Associação entre material particulado de queimadas e doenças respiratórias na região sul da Amazônia brasileira. Revista Panamericana de Salud Pública, 27, 10-16. Retrieved from https://www. scielosp.org/pdf/rpsp/2010.v27n1/10-16/pt

Case M. (2006). Climate Change Impacts in the Amazon: Review of the Scientific Literature (World Wildlife Fund) 8th Conference, of the Parties, to the Convention on Biological Diversity (pp. 20-31). Retrieved November 27, 2019 https://d2ouvy59p0dg6k.cloudfront.net/ downloads/amazon_cc_impacts_lit_review_final_2.pdf

Cook, B. I., Smerdon, J. E., Seager, R., \& Coats, S. (2014). Global warming and 21st century drying. Climate Dynamics, 43, 2607-2627. Retrieved from http://www.readcube.com/ articles/10.1007/s00382-014-2075-y

Davidson, E. A., de Araújo, A. C., Artaxo, P., Balch, J. K., Brown, I. F., Bustamante, M. M. C., et al. (2012). The Amazon basin in transition. Nature, 481, 321-328. Retrieved from https:// www.nature.com/articles/nature 10717

FAO (2011). The State of Forests, in the Amazon Basin, Congo Basin and Southeast Asia. Retrieved from http://www.fao.org/3/i2247e/i2247e00.pdf

Fowler. (2003). Human health impacts of forest fires in the southern United States: A literature review. Journal of Ecological Anthropology, 7, 39-63. Retrieved from https://scholarcommons. usf.edu/jea/vol7/iss $1 / 3 /$

Faustini, A., Alessandrini, E. R., Pey, J., Perez, N., Samoli, E., Querol, X. et al. (2015). Short-term effects of particulate matter on mortality during forest fires in Southern Europe: results of the MED-PARTICLES Project. Occupational and Environmental Medicine, 72, 323-329. https:// doi.org/10.1136/oemed-2014-102459

Frankenberg, E., McKee, D., \& Thomas, D. (2005). Health consequences of forest fires in Indonesia. Demography, 42, 109-112. Retrieved from https://link.springer.com/article/10.1353/ dem.2005.0004

Gaffney, O., Crona, B., Dauriach, A., \& Galaz, V. (2018). Sleeping financial giants: Opportunities in financial leadership for climate stability. Retrieved from https://sleepinggiants.earth/wpcontent/uploads/2018/09/Sleepingfinancial-giants-report-24-September-2018.pdf

INPE. (2019). Retrieved from http://www.obt.inpe.br/OBT/assuntos/programas/amazonia/prodes

Johnston, F., Hanigan, I., Henderson, S., Morgan, G., \& Bowman, D. (2011). Extreme air pollution events from bushfires and dust storms and their association with mortality in Sydney, Australia 1994-2007. Environmental Research, 111, 811-816. Retrieved from https://www.sciencedirect.com/science/article/pii/S0013935111001241?via\%3Dihub

Longo, M., Saatchi, S., Keller, M., Ferraz, A., Bowman, K. W., Bloom A. A., et al. (2018). Tropical forest structure modulates flammability and response to extreme droughts in the Amazon. American Geophysical Union. Retrieved from http://adsabs.harvard.edu/abs/2018AGUFM. B31K2630L 
Lovejoy, \& Nobre. (2018). Amazon tipping point. Science Advances, 4(2), eaat2340. Retrieved from http://advances.sciencemag.org/content/advances/4/2/eaat2340.full.pdf

Machin, A. B., Nascimento, L. F., Mantovani, K., \& Machin, E. B. (2019). Effects of exposure to fine particulate matter in elderly hospitalizations due to respiratory diseases in the South of the Brazilian Amazon. Brazilian Journal of Medical and Biological Research, 52, e8130. https:// doi.org/10.1590/1414-431X20188130

Marengo, J. A., Souza, C. M., Thonicke, K., Burton, C., Halladay, K., Betts, R. A., et al. (2018). Changes in climate and land use over the Amazon region: Current and future variability and trends. Frontiers Earth Science, 6, Article 228. Retrieved from https://www.frontiersin.org/ articles/10.3389/feart.2018.00228/full

Morgan, G., Sheppeard, V., Khalaj, B., Ayyar, A., Lincoln, D., Jalaludin, B., et al. (2010). Effects of bushfire smoke on daily mortality and hospital admissions in Sydney, Australia. Epidemiology, 21, 47-55. Retrieved from https://insights.ovid.com/pubmed?pmid=19907335

Nobre. (2014). O Futuro Climático da Amazônia: Relatório de Avaliação Científica. Articulación Regional Amazónica, 1, 42. Retrieved from http://www.pbmc.coppe.ufrj.br/documentos/ futuro-climatico-da-amazonia.pdf

Nunes, K. V. R., Ignotti, E., \& de Souza Hacon, S. (2013). Circulatory disease mortality rates in the elderly and exposure to PM2.5 generated by biomass burning in the Brazilian Amazon in 2005. Cadernos de Saúde Pública, 29, 589-598. Retrieved from http://www.scielo.br/pdf/csp/ v29n3/a16v29n3.pdf

RAISG (2015). Deforestación en la Amazonia (1970-2013). Retrieved from https://www.amazoniasocioambiental.org/es/publicacion/deforestacion-en-la-amazonia-1970-2013-atlas/

Rittmaster, R., Adamowicz, W. L., Amiro, B., \& Pelletier, R. T. (2006). Economic analysis of health effects from forest fires. Canadian Journal of Forest Research, 36, 868-877. Retrieved from https://www.nrcresearchpress.com/doi/abs/10.1139/x05-293\#.XJ9Xk5hKjIV

Salati, E., Dall'Olio, A., Matsui, E., \& Gat, J. R. (1979). Recycling of water in the Amazon, Brazil: An isotopic study. Water Resources Research, 15, 1250-1258. Retrieved from https://agupubs. onlinelibrary.wiley.com/doi/abs/10.1029/WR015i005p01250

Sankaran, \& Sheldon. (2018). Transboundary pollution in Southeast Asia: Welfare and avoidance costs in Singapore from the forest burning in Indonesia. "Boston College Working Papers in Economics 960, Boston College Department of Economics." American Geophysical Union, Fall Meeting 2018, abstract \#GH11C-0923. Retrieved from http://adsabs.harvard.edu/ abs/2018AGUFMGH11C0923S

Tan-Soo, \& Pattanayak. (2019). Seeking natural capital projects: Forest fires, haze, and early-life exposure in Indonesia. Proceedings of the National Academy of Sciences of the United States of America, 116, 5239-5245. Retrieved from https://www.pnas.org/content/pnas/116/12/5239. full.pdf

UNEP. (2018). Emissions Gap Report. Retrieved from http://wedocs.unep.org/bitstream/ handle/20.500.11822/26895/EGR2018_FullReport_EN.pdf

Viana, (2017). Too big to fail: A roadmap for sustainable development of the Amazon. In: II International Conference on Sustainable Development, SDSN, New York.

Viana, (2019). Não há desenvolvimento sem proteção ambiental. El Pais Brasil. Retrieved from https://brasil.elpais.com/brasil/2019/03/15/opinion/1552674544_685747.html

WHO (2019). Ambient air pollution - A major threat to health and climate. Retrieved from https:// www.who.int/airpollution/ambient/en/

WWF (2018). Wildlife in a warming world. Retrieved from https://c402277.ssl.cf1.rackcdn.com/ publications/1149/files/original/WWF__-Wildlife_in_a_Warming_World_-_2018_FINAL. pdf?1520886759 
Open Access This chapter is licensed under the terms of the Creative Commons Attribution 4.0 International License (http://creativecommons.org/licenses/by/4.0/), which permits use, sharing, adaptation, distribution and reproduction in any medium or format, as long as you give appropriate credit to the original author(s) and the source, provide a link to the Creative Commons license and indicate if changes were made.

The images or other third party material in this chapter are included in the chapter's Creative Commons license, unless indicated otherwise in a credit line to the material. If material is not included in the chapter's Creative Commons license and your intended use is not permitted by statutory regulation or exceeds the permitted use, you will need to obtain permission directly from the copyright holder.

(c) (i) 